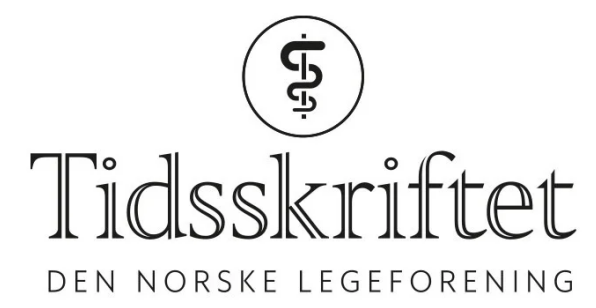

\title{
Selvskading og idrett - en kasuistisk tilnærming
}

KRONIKK

\section{FINN SKÅRDERUD}

Email: finns@online.no

Høgskolen i Lillehammer

2626 Lillehammer

Avdeling for helse- og sosialfag

Toppidrett handler om å presse grenser for kropp og sinn. Dette kan føre til at man innfrir toppidrettens mål og mening, at man vinner. Men å sette det grenseoverskridende i system, kan også bety risiko for psykiatriske symptomer. Denne kronikken belyser gjennom kasuistiske eksempler flere mulige sammenhenger mellom toppidrett og selvskading.

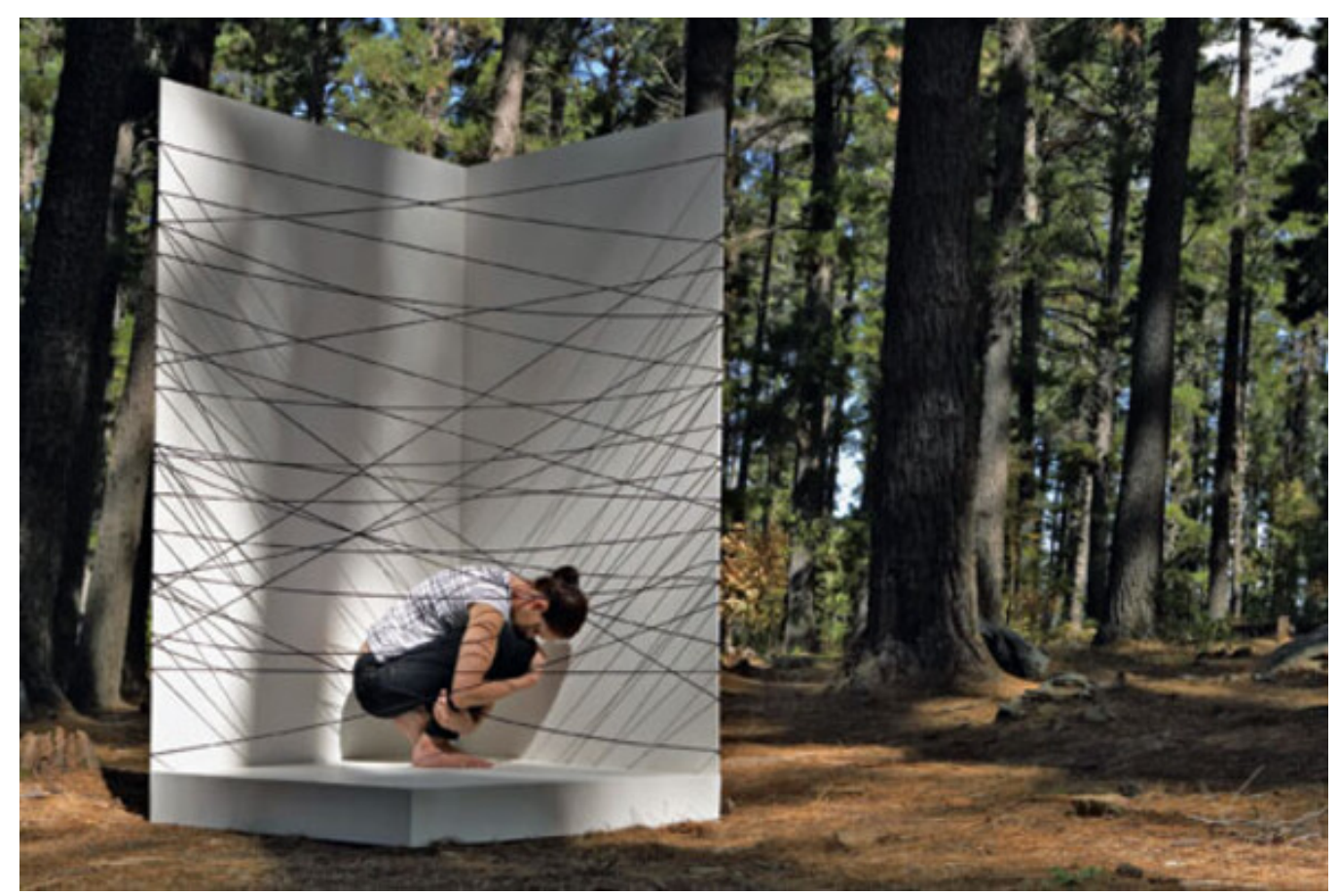


Idrett representerer mestring, og det er velkjent at fysisk aktivitet kan være gagnlig for mental helse, eksempelvis ved depresjoner. Men idrett kan også representere merbelastninger og stress, og slik bidra til psykiske plager (1). I USA er idrettspsykiatri et eget fagfelt (르). Idrettspsykiatrisk virksomhet skiller seg fra idrettspsykologi ved at det primære siktemålet ikke er å fremme prestasjoner, men å fremme den psykiske helsen hos utøverne. Å arbeide med spiseforstyrrelser har vært og er en sentral del av en slik terapeutisk virksomhet, gitt den relative overhyppigheten av slike fenomener innenfor dans og toppidrett (3). Selvskading er også blitt et mer synlig fenomen hos idrettsutøvere de aller siste årene, slik vi ellers ser i forskjellige helsekontekster og i ungdomskulturen generelt $(4,5)$. Med synlighet siktes det her til at selvskading hos idrettsutøvere i økende grad er henvisningsgrunn og tema i de terapeutiske møtene. Om en slik opplevd økt synlighet skyldes en $ø$ kt oppmerksomhet omkring selvskading eller faktisk $\emptyset \mathrm{kt}$ forekomst, er vanskelig å si. Meg bekjent finnes det foreløpig ikke studier om forekomst av selvskading i denne populasjonen.

Jeg har siden 1999 vært tilknyttet Olympiatoppen for å bistå utøvere med symptomer på psykiatriske lidelser. I denne kronikken vil jeg ved kortfattede kasuistiske illustrasjoner vise hvordan selvskading kan komme til uttrykk i idrettslige sammenhenger. Teksten bør leses som en introduksjon til et lite utviklet kunnskapsfelt. De tre eksemplene er strategisk valgt ut for å fremheve selvskadens mangfoldige fenomenologi innenfor en idrettskontekst og for å tydeliggjøre forskjeller, mer enn fellestrekk ved fenomenene. Det første kasus er hentet fra en topputøvers selvbiografiske tekst, og er slik sett allment tilgjengelig. Kasus 2 er anonymisert og biografisk omskrevet. Kasus 3 er konstruert på grunnlag av en rekke pasienter, slik at de faktiske personene bak ikke er gjenkjennelige. Jeg mener imidlertid at den psykologiske essensen fra de opprinnelige fortellingene er godt ivaretatt til tross for fiksjonaliseringen

\section{Kasus 1 - idrettsrelatert depresjon}

Kildegrunnlaget er en selvbiografisk tekst, og medieoppmerksomheten i forbindelse med lanseringen av denne (6.6.7). Den engelske friidrettsutøveren Kelly Holmes (f. 1970) vant dobbelt gull i sommer-OL $i$ Athen $i$ 2004, i distansene $800 \mathrm{~m}$ og $1500 \mathrm{~m}$. Hun ble straks en britisk superstjerne. I den åpenhjertige selvbiografien fra 2005 beskrev hun en urolig oppvekst med rasemiks og oppsplitting av familien (6). Moren er av engelsk opprinnelse, mens faren kommer fra Jamaica. Dette forklarer selvbiografiens tittel «Black, white and gold». Hun skrev også om en rekke tøffe utfordringer som soldat $i$ den britiske haren før hun for alvor satset på idrettskarrieren.

Selvbiografien vakte ikke minst oppsikt fordi hun i forbindelse med lanseringen fortalte om sin selvskading. 14 måneder før OL $i$ Athen var hun svcert frustrert over smertefulle idrettsskader. I selvbiografien beskrev hun at hun i sterk fortvilelse låste seg inne på badet, skrudde på kranene for å dempe lyden av sin gråt og begynte å skade seg i huden med en saks. Hun skadet seg slik regelmessig på armene, mage og bryst. «I made one cut for every day I had been injured. With each one I felt I was pushing myself, but at the same time I felt a sense of release that drove me to do it again.» (7.). Hun holdt selvskadingen skjult for trenere, familie og venner. Etter en tid kontaktet hun en lege som diagnostiserte en depressiv tilstand. Etter to måneder med repetitiv selvskading klarte hun å stanse dette, og beskrev det i selvbiografien som et tilbakelagt stadium. «For me success is definitely the best therapy."

Tilfellet Kelly Holmes knytter den selvskadende aktiviteten direkte til mentale belastninger som toppidrettsutøver. Depresjon og affektiv dysregulering er generelt beskrevet som sentrale komorbide trekk ved selvskading ( $\underline{8})$. Kelly Holmes attribuerer den depressive affekten, og det at hun kutter seg, til fortvilelsen over kanskje ikke å nå helt til topps i OL. Hun knytter selvskading som meningsbærende praksis til to fenomener, henholdsvis å straffe seg selv og å anvende den fysiske skaden som en mestringsteknikk for å lindre 
psykologisk smerte. Kelly Holmes beskriver også hvordan selvskading for henne faktisk virket som affektregulering, og derfor representerte en stimulans til repetitiv påføring av smerte.

\section{Kasus 2 - relasjonstraumer}

Lene, i 20-årene, driver med en lagidrett. Fra begynnelsen av tenårene ble hun utsatt for seksuelle overgrep gjennom flere år fra en stefar. Da hun etter lengre tid våget å si fra om dette, på tross av overgripers trusler om straff, fikk hun liten støtte fra sin mor og øvrige familie. Senere i tenårene utviklet hun atferdsproblemer og vanket i en periode i miljøer som var belastet med rus. Her ble hun retraumatisert i form av å bli gruppevoldtatt.

Da hun begynte i psykoterapeutisk behandling, hadde hun skadet seg selv regelmessig i en årrekke. I begynnelsen hadde det dreid seg om kutt på underarmene. Sårene og arrene ble raskt en bekymring med tanke på at de ble eksponert i idrettslige sammenhenger. Hun begynte å slå seg selv mot hodet, på slike vis at det etterlot minimalt med fysiske tegn. Hun brukte også høyintensiv trening som selvskadende aktivitet. Hun spiste lite og la ut på harde løpeturer. Intensjonen var ikke å fremme prestasjoner, men å utmatte seg $i$ en slik grad at hun følte seg sløv og nummen i forhold til negativt tankekjør og emosjonelt kaos. I andre situasjoner kunne hun ty til den selvskadende atferden som en teknikk for å bringe seg selv ut av dissosiative tilstander (4,9). Hennes tilstand, bl.a. med høyt angstnivå, urolig søvn, mareritt, flashbacks og dissosiative symptomer, kvalifiserte til diagnosen posttraumatisk stresslidelse (9):

Lene attribuerte ikke sin selvskadende atferd til idrett. Tvert imot, hun opplevde idretten som en trygg havn i en utrygg oppvekst. Der fant hun et alternativt og støttende voksenmiljø. Og gode idrettsprestasjoner fungerte som positivt påfyll for en ung person med skadet selvfølelse.

I dette tilfellet knyttes selvskaden til traumatiske erfaringer, særlig i form av relasjonstraumer i barne- og ungdomsårene. Slike traumer er kjente risikofaktorer for selvskade og for posttraumatisk stresslidelse (4). Eksemplet illustrerer hvordan fysisk aktivitet psykologisk sett kan fungere som selvskading med affektregulering som motivasjon. Den idrettslige konteksten gjør det lettere for den selvskadende personen å skjule disse egentlige motivene for omgivelsene. Dysfunksjonell og patologisk aktivitet er maskert som normalaktivitet, og det blir vanskelig å skille syk fra flink.

\section{Kasus 3-spiseforstyrrelse}

Anna, 24 år, ble diagnostisert med anorexia nervosa (9). i tenårene. Tett oppfølging bidrar til at hun inntar et nødvendig minimum av ncering daglig, og at hennes undervekt blir oppfattet som moderat. Den sterkeste motivasjonen for å spise har lenge vart truslene om å bli tatt ut av laget om hun faller under en definert minstevekt. I perioder evner hun å yte på et relativt høyt nivå innenfor sin idrett. I andre perioder bidrar både for dårlig erncering, mentalt stress og depressiv affekt til svake prestasjoner.

Anna har et ambivalent forhold til idrettsmiljøet. Hun ønsker seg ofte vekk. Hun opplever prestasjonskulturen som psykisk svert belastende. Samtidig sier hun at hun ikke kjenner noe annet liv. Hun nerer sin selvfølelse gjennom prestasjoner. Idrett har ved siden av prestasjoner på skolen fylt det meste av hennes ungdomstid. Hun er derfor lite sosialisert innenfor andre ungdomsarenaer. Hun sier at hun føler at idretten ødelegger henne, men at uten idretten vil hun bli ødelagt, fordi hun «blir ingen». Hun er også engstelig for at hun skuffer andre dersom hun slutter som topputøver. Det har vert en rekke episoder helt fra barneårene hvor foreldrene har reagert med skuffelse, irritasjon og sinne når Anna ikke har lyktes $i$ konkurranser.

Anna opplever idrettens sterke kroppsfokus som en belastning. Flere av de andre på laget viser også tegn på spiseforstyrrelser, og en scerlig belastning er hvordan de kvinnelige utøverne stadig sammenlikner seg med hverandre. I perioder kan Anna oppleve konkurranse om ikke bare å vcere best, men også om å spise minst. Hun kjenner, som flere av de andre, en egen spenning $i$ å balansere mellom å spise lite nok og å prestere godt nok. 
I perioder hvor hun er ekstra misfornøyd med sin kropp, som når hun en tid har samarbeidet godt med behandler og har spist rimelig sunt og fornuftig, kan hun ty til selvskade i form av kutting. Hun sier at hun søker den selvpåførte smerten for å regulere den besettende kropps- og livsmisnøyen som er knyttet til hennes anoreksi. Hun har en relativt god innsikt i sin lidelse, men dårlig kontroll over sine affekter og ageringer.

Anna er valgt som eksempel for å illustrere komorbiditet mellom selvskading og spiseforstyrrelser (5). Eksemplet belyser også familiesamspill hvor voksne legger press på sine barn. I barne- og ungdomspsykiatriske kontekster er det særlig interesse knyttet til begrepet "prestasjon på vegne av andre» (achievement by proxy). Det innebærer psykologiske konsekvenser av å være barn og ungdom som drives frem til ytelser av voksne (10). Dette er en tematikk som er gjenkjennelig fra egen klinisk og psykoterapeutisk praksis med toppidrettsutøvere og som peker mot utviklingspsykologiske betingelser for utvikling av selvfølelse, identitet og psykisk helse.

\section{Oppsummering}

De tre ovenstående eksemplene illustrerer forskjellige aspekter ved selvskading som fenomener innenfor toppidrettskontekster. Et fellestrekk er at selvskading i alle tre tilfeller blir erfart som kroppspraksiser som tjener selv- og affektregulering (4,.5). Utover det belyses selvskading som en respons på mentale belastninger i en toppidrettskontekst, selvskading som selvstraffende aktivitet, selvskading i kjølvannet av relasjonstraumer og selvskading relatert til spiseforstyrrelser. Det ene kasuistiske eksemplet viser også hvordan idrettsaktiviteter, som høyintensiv trening, kan fungere som selvskadende atferd.

Det er et uunngåelig faktum at toppidrett representerer belastninger som igjen er risikofaktorer for psykiske plager, slik toppidrettslivet også kan være knyttet til gode opplevelser av mestring og nærende relasjoner (1). Belastningene kan oppleves i form av selve konkurranse- og ytelsespresset, «utbrenthet», lite tid til hvile og sosialisering utenfor idretten, stor reiseaktivitet med konsekvenser for parrelasjoner og familieliv m.m. Og siden idrett representerer et betydelig fokus på kropp og ernæring, er det nærmest logisk at kroppen kan bli «åstedet» for enkelte psykopatologiske ytringer, som ved selvskading og spiseforstyrrelser (1). I tillegg er det slik at en del personer med sterke belastninger i sin livshistorie, jevnfør kasus 2, søker seg til idretten som et alternativt og belønnende miljø. Gitt slike risikoforhold er det absolutt nødvendig med kompetanseutvikling omkring de idrettsspesifikke belastningene på utøverne. Slik kompetanse er hensiktsmessig ikke bare for å fremme gode møter med utøvere i behandling, men også for rådgivning, veiledning og forebygging i forhold til trenere, ledere, støtteapparat og familie.

Ved Olympiatoppen, gjennom Helseavdelingen ved Toppidrettsenteret i Oslo, har det i lengre tid vært tilknyttet psykiater. Mange av utøverne opplever det som trygghetsskapende å møte behandlere innenfor sine egne kontekster og som kjenner spesielt godt til deres livs- og virksomhetsbetingelser. Det ligger en særlig utfordring og åpenbar ressurs i å få til gode og åpne dialoger med trenere og ledere omkring utøverens relativt tabubelagte plager.

Det aller meste av idrettsaktivitet foregår ikke på et toppidrettsnivå, men vi må anta at en del av det som er beskrevet i disse kasuistikkene, også har relevans for breddeidretten, og således for en rekke leger. Slike beskrivelser kan forhåpentligvis bidra til økt årvåkenhet overfor mulige sammenhenger mellom selvskading og idrett.

\section{Oppgitte interessekonflikter:}

Ingen 
1. Skårderud F. Portrett av atleten i nød. I: Loland S, red. Toppidrettens pris. Oslo: Universitetsforlaget, 1998: 71-88.

2. Begel D. An overview of sport psychiatry. Am J Psychiatry 1992; 149: 606-14.

3. Sundgot-Borgen J, Skårderud F, Rodgers S. Eating disorders among athletes and dancers. I: Treasure J, Schmidt U, van Furth E, red. Handbook of eating disorders. 2. utg. Chichester, West Sussex: Wiley, 2003:385-400.

4. Sommerfeldt B, Skårderud F. Hva er selvskading? Tidsskr Nor Legeforen 2009; 129: 754-8.

5. Skårderud F, Sommerfeldt B. Selvskading og spiseforstyrrelser Tidsskr Nor Legeforen 2009; 129: 877-81.

6. Holmes K. Black, white and gold. My autobiography. London: Virgin Books, 2005.

7. Holmes 'reveals self-harm plague'. BBC news 29.5. 2005. http://news.bbc.co.uk/1/hi/uk/4591581.stm (29.1.2009).

8. Herpertz S. Self-injurious behavior. Psychopathological and nosological characteristics in subtypes of self-injurers. Acta Psychiatr Scand 1995; 91: 57-68.

9. WHO. ICD-10. Psykiske lidelser og atferdsforstyrrelser. Oslo: Gyldendal, 2002.

10. Tofler IR, Knapp PJ, Drell MJ. The «Achievement by Proxy» spectrum: recognition and clinical response to pressured and high-achieving children and adolescents. J Am Acad Child Adolesc Psychiatry 1999; 38: 213-6.

Publisert: 30. april 2009. Tidsskr Nor Legeforen. DOI: 10.4045/tidsskr.08.0455

Manuskriptet ble mottatt 2.11. 2008 og godkjent 26.2. 2009. Medisinsk redaktør Siri Lunde.

(C) Tidsskrift for Den norske legeforening 2023. Lastet ned fra tidsskriftet.no 26. april 2023. 